\title{
INDIGENOUS SOCIAL MOVEMENTS IN THE AMERICAS
}

\author{
Introduction
}

T he present issue of the Review of International American Studies explores selected cases of Indigenous resistance to oppressive forms of environmental, socio-economic, linguistic, and cultural colonialism. Looking at both multi-tribal and single-tribal contexts, the authors look at the Dakota Access Pipeline protests, the novels of Lakota/Anishinaabe writer Frances Washburn, the Two Spirit movement in the U.S., and the Indigenous food sovereignty movement in the U.S. and Peru as sites of creative forms of decolonizing resistance, and analyze the material, discursive, and cultural strategies employed by the Indigenous activists, writers, and farmers involved.

In the first article of the issue, "'Fires were lit inside them': The Pyropolitics of Water Protector Camps at Standing Rock", Elizabeth Hoover utilizes Michael Marder's concept of pyropolitics to analyze the literal and metaphorical uses of fire to protect water from industrial capitalism during the Dakota Access Pipeline protests at Standing Rock. Following a discussion of the numerous ways in which fire has been used at the camps (for instance, as cooking fire and ceremonial fire), the author describes how the "sparks ignited at Standing Rock" have been taken home by the activists to other struggles against the building of pipelines, the contamination of water, and the appropriation of Indigenous land. The article is based on ethnographic research conducted by the author during her visits to Standing Rock during the protests.

Zuzanna Kruk-Buchowska Faculty of English Adam Mickiewicz University in Poznań Poland

Jenny L. Davis Dept. of Anthropology University of Illinois, Urbana-Champaign USA

Guest Editors

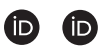


In "'Bringing Things Together': Tribalography, Lakota Language, and Communal Healing in Frances Washburn's Elsie's Business and The Sacred White Turkey", Joanna Ziarkowska applies LeAnne Howe's concept of tribalography to look at how Indigenous communities presented in the two novels engage in practices of cultural revival, such as storytelling, speaking Lakota language, and observing Lakota ceremonies in a colonial context. However, preserving Indigenous culture is seen as more than just an act of resistance: it is an act of healing and restoring of harmony in troubled communities.

Next, Jenny Davis offers an analysis of the discursive strategies within Two Spirit events and groups that emphasize the definition of 'Two Spirit' as an Indigenous identity. In the article "Refusing (Mis)Recognition: Navigating Multiple Marginalization in the U.S. Two Spirit Movement", she points to the fact that the necessity to negotiate between unifying Native American terms as well as culturally- and community-specific terms burdens members of the already multiply marginalized community. By referring to Audra Simpson's concept of the politics of refusal, she argues that Two Spirit Individuals refuse such categorizations and the dichotomies implied in them.

The last two articles in the issue deal with Indigenous food sovereignty. In her article, "Traditional Ecological Knowledge and Indigenous Foodways in the Andes of Peru", Mariaelena

Indigenous Social Movements in the Americas Huambachano offers a comparison of the traditional foodways of the Choquecancha and Rosaspata Quechua communities in the Peruvian Andes, where she has conducted ethnographic research. In applying the lens of Traditional Ecological Knowledge (TEK), she seeks to address its diversity and complexity in the context of Quechua sustainable food systems, and she proposes an Indigenous-based theoretical model of food sovereignty based on these communities' TEKs. At the same time, she considers the impact of Indigenous peoples' knowledge for global food security.

Last, Zuzanna Kruk-Buchowska looks at the role of the traditional foodways of the Oneida Nation of Wisconsin in their contemporary food sovereignty efforts. In her article titled "Food Sovereignty Practices at the Oneida Nation of Wisconsin Tsyu- 
nhehkw^ farm: The Three Sisters, Ceremony and Community", she looks at the work of the tribe's organic farm, Tsyunhehkw^ (joon-hen-kwa), which serves important cultural, economic, and educational purposes for the community and provides it with traditional crops, such as white corn and tobacco, which are used in Oneida ceremonies. Based on interviews conducted with the farm's employees, she considers their understandings of the continuity of food and agricultural traditions, such as the Three Sisters (corn, beans and squash) in the community.

Zuzanna Kruk-Buchowska and Jenny L. Davis RIAS Guest Editors

Zuzanna Kruk-Buchowska Faculty of English Adam Mickiewicz University in Poznań Poland

Jenny L. Davis

Dept. of Anthropology University of Illinois, Urbana-Champaign USA

Guest Editors 
